\title{
Anchored in Justice: Yorùbá Philosophy and the Politics of a Diverse State
}

\author{
Segun Gbadegesin \\ Department of Philosophy \\ Howard University, \\ United States \\ agbadegesin@howard.edu
}

\begin{abstract}
As a major ethnic nationality in the multinational state cobbled together and christened by Lord Frederick Lugard, the Yoruba have been an integral part of the politics of the Nigerian diverse state since 1914. From the vicissitudes of the politics of nationalist struggles against colonial imposition to the politics of independence and nation-building, the core traditional values and philosophical outlook of each of the ethnic nationalities are discernible in their approaches to the issues that confront the new state. In this paper, I identify the core traditional values of the Yoruba nationality. I focus specifically on the Yoruba fascination with justice as a guiding principle as they relate to other nationalities in dealing with the issues that confront the new state. I argue that this fascination is not an arbitrary recourse in the politics of the new state. Rather, obsession with justice has been a defining feature of intra-Yoruba dealings from precolonial times to the present. To illustrate, I recount a few historical and mythical examples from the radical and unconventional social critics, Kọú Ọjà, Oppálábà and Aróhánrán of the Old Ọyọ Empire, to the historical Àarẹ Kúrunmí of İjàyè. Finally, I highlight a few episodes in the political development of Nigeria and the role that the Yoruba obsession with justice has played in the political journey of the country.
\end{abstract}

Keywords: Justice, Nigerian state, Yorùbá politics, Tradition, Metaphysical equality 


\section{Introduction}

Analysis and clarification of philosophical concepts that feature in non-Western cultures have been unduly framed as a comparative analysis in which similarities and differences with Western concepts occupy the central spotlight. While I do not deny the usefulness of that approach, it is not my interest here. My approach here differs in two respects. First, I am not interested in whether the Yorùbá, in particular, or non-Western cultures, in general, have a worldview that is compatible with or can accommodate the requirement of Western concepts of justice. In any case, the requirements of justice have been conceived in various ways in Western culture. And since the various Western conceptions are motivated in part by the different conceptions of persons in relation to society and government, one cannot rule out of court an authentic Yorùbá or non-Western conception of justice, which is compatible with a specific conception of persons, society, or government. Such a conception, if available, may then be used as a basis for judgments of justice in various social and political contexts. Secondly, my interest here is not a conceptual analysis. That is, I am not interested in analyzing the concept of justice. Rather, I am interested in a narrative discourse of the role that justice plays in Yoruba politics both internally, in relation to their fellow ethnic-nationals, and externally, in relation to other ethnic-nationalities in the Nigerian state. In what ways do perceptions of justice or injustice motivate the Yorùbá to act or refrain from acting in different situations? I address this question by looking at few snapshots of cultural, social, and political practices from precolonial times to the present.

\section{The Social Contexts of Justice}

There is a pertinent observation that there appears to be a consensus among scholars of Western and non-Western cultures that while Western social life is individualistic, non-Western social life is communalistic. John Stuart Mill is the philosopher of Western individualism, and scholar-statesmen from Nkrumah to Nyerere and Senghor have made much of what they consider as the communal orientation indigenous to traditional Africa. But as I have argued elsewhere, communalism is not unique to Africa (Gbadegesin 1991), as it is characteristic of all traditional societies, including those of the West. Various philosophical explorations account for its prevalence in such societies, including the historical materialism of Marx and the spiritual humanism of Senghor. Face-to-face material existence in the absence of technological development can elicit the practice of communalistic living among a people. The important point, however, is that issues of what is just are always 
at the core of social life no matter how communalistic or individualistic the social context is. Consider the following social contexts:

1. A husband/father in a polygamous home is accused of favoring one wife and her children over others.

2. A community protests the high-handedness of its ruler(s).

3. A high chief rebels against his paramount ruler for violating tradition.

4. A people reject as unjust the imposition of an external power over them without their consent.

5. A social critic's lampooning of the system of punitive justice in his community changed the system.

Each of these five contexts is a narrative of an occurrence, real or mythical, in Yorubáland. In each of them, the centrality of justice as the motive force of action or reaction is inescapable.

\section{Justice in the Family Context}

Consider the first context: the family as the basic unit of social life. In traditional Yoruba society, the husband is the recognized head of the family. As such, he is expected to be fair in his dealings with his wife (or wives) and children. He cannot fairly show preference for one over the others. Besides being unfair, it is also considered imprudent because it can damage the family cohesion in the long run. This judgment of justice in family relationship is not confined to polygynous contexts. It is invoked even in monogamous relations when the husband is intolerant or abusive. And as it has been pointed out elsewhere, the Yorùbá do not countenance unfairness even from their deities (ibid). Orúnmilà, the god of wisdom, is the object of harsh judgment for the way in which he treated İwà, his wife. İwà was a dutiful wife. Like everyone, however, she was not unqualifiedly good. For instance, in Òrúnmilà's assessment, she was not very good at housecleaning. As a man of the people with many clients looking for insight into their future through divination, Orúnmilà wanted his house to be clean at all times. Therefore, he took exception to İwà's poor hygiene and constantly harassed her. Fed up, İwà packed out of Òrúnmilà's house and went to live with Sùúrù, her father. The consequence for Òrúnmìà was instant and devastating. His clients stopped visiting and his business was on the verge of ruin. They accused him of unfairness to his wife. Apparently, İwà's presence in the house had been a crowd puller. Òrúnmilà swallowed his pride and embarked on a journey to beg İwà to give him a second chance. If the god of wisdom is presented in this light, it is a lesson to mortals that they will not be spared if they are found unfair. 


\section{Justice in the Community Context}

This affirmation of the importance of justice and fairness in family relation is projected onto the community and the king-subject relation that it entails. For the sake of community peace, and as the father of all, the king is expected to be tolerant and fair to all. Though the subjects recognize their king as an authority second only to the gods (aláse èkejì òị̀à), and the king's title, Kábíyèsí (no one can question his authority), implies that the king has absolute authority; the community does not tolerate high-handedness on the part of the king. Whenever they perceive such, there is bound to be protest. This is a no-brainer. A people who disdain unfairness by deities cannot be expected to countenance the same by their king, who is subservient to the deities. The mindset that challenges the deity to avoid worsening their condition if he or she is incapable of improving it (òrị̣à bóò leè gbè mí, fi mí sílẹ bóo ti bá mí) will, by the same token, resist any attempt by their earthly kings to aggravate their social life. Perceptions of the violation of this basic principle of social life are at the center of the various civil unrests in pre-colonial Yorùbáland. An example from one community will suffice.

Okeho is a community in the northern fringes of Oyo State. Like many such communities in nineteenth-century Yorùbáland, the Okeho story started with a prince, Òjó Orónnà, from Ilaro, who went into voluntary exile because he considered the process that passed him over for the throne to be unjust. ${ }^{1}$ His adventure took him to Omogudu with his family and supporters who made him the chief of their newfound home. Not too far from there was Olofin, an herbalist, who had settled in the vicinity with his family and who became a close confidant of the new arrival. Five generations later, there were eleven villages as neighbors, each with its own head, and each minding its own business. It soon occurred to them that there was immense advantage in coming together, especially to ward off and protect themselves against the aggression of the Dahomey and Fulani forces. This unification occurred during the reign of Arilesire, a period which saw a lot of unrest in Yorùbáland. Surrounding towns, such as Osoogun, the home of Bishop Ajayi Crowther, had been sacked by slave raiders. It was prudent for small villages to bind together in a safe environment, such as was provided by İjò, a village surrounded by mountains and hills. Arilesire, the head of Ijò, invited his neighbors to join him for safety and they gladly accepted. Thus, Okeho was founded.

But the villages that came together to found Okeho chose not to merge, but rather to form a confederacy of sorts with security as the common purpose and the basis of the association. While each village became a neighborhood in Okeho, each retained for itself as much power as was not needed in the matter

1 See Ladele and Oyedemi (1979, and Gbdegesin, 2017. 
of safety and protection from external sources. Each was still responsible for the economic well-being of its people and for resolving any civil or criminal cases that arose within its borders. However, their new landlord was Arilesire, the "Onjò" and as such, he had an advantage. He was an herbalist and weaver while other neighborhood or compound heads were farmers. While the latter had to venture out to their farms, sometimes for days, Arilesire was a stay-at-home village head. Therefore, the farmers would sometimes appeal to Arilesire to help them solve any problems that might arise within their compounds in their absence. When they were around, they met in the compound of Arilesire to deliberate on the issue of safety and protection and they commonly attended to whatever ritual was required. Beyond this attention to common issues, the various "villages-become-compounds" still minded their own business until the arrival of the British overlords who introduced a new system that offended the sensibilities of the people.

The new overlords failed to pay attention to the simple fact that independence is the yearning of every human being, educated or illiterate. Struggling with and against nature and its many inhibitions was frustrating enough. Being hamstrung by fellow human beings was an additional insult that must be resisted. And so, from time to time, trouble came the way of colonial administrators from the least expected sources, especially in the matter of agitation against the high-handedness of chiefs who they perceived were conspiring with external powers, including the Alaafin, to trample on tradition. Okeho was one such source of sporadic trouble.

As explained above, the tradition of Okeho upon its founding was confederacy. While other village or neighborhood heads relied on Onjò to solve problems within their domain when they were away in the farms, they resented the new powers conferred upon him by external forces who needed a ruler to take charge of the entire town. Other ten village heads felt disadvantaged with predictable result. They conspired to depose one Onjò after the other and in cases where the Colonial Resident intervened to reinstate the Onjò, the chiefs and the people did not hesitate to eliminate the unwanted Onjò. This was the case in 1895 when Captain Bower reinstated Labiyi who had been dethroned twice by the people. Labiyi was killed thereafter, making the dethronement rather permanent.

The foregoing was only a prelude to what happened in 1916 when Okeho and Iseyin were sacked by the forces of Captain Ross. Some of the grievances of the people of Iseyin and Okeho included the introduction of forced labor for the construction of roads, courts, and a rest house for the white resident, as well as forced taxation. It did not help matters that they also accused their chiefs as co-conspirators with the British colonialists. In addition, the introduction of the court system was alien to the culture of the people who had 
always relied on the wisdom of the chiefs to resolve amicably any issues between them. From September 26, 1916, Iseyin and Okeho planned the attack and on October 19, Okeho struck, killing Onjò Olúkìtibí, one of his chiefs, and some of his aides. They razed the court and the palace. On October 21, Iseyin struck, killing a Colonial Officer, a court messenger and some others. They also burned down the court. Captain Ross's response was swift. He sacked Iseyin, killed many of the rioters and condemned the captured to death by hanging. Okeho was relocated to a more open and accessible location where it has been to date (Atanda 1969). Though they were subdued, it was clear to the colonizers that the people openly and bravely expressed their opposition to what they perceived as an unjust imposition of alien rule with its strange customs and conventions which trampled upon their traditional understanding of social and political life.

\section{Justice as Respect for Tradition}

Tradition was also at the center of the rebellion of Kúrunmí, the nineteenth-century army general of Oyo kingdom. As Are Ona Kankanfo (Field Marshall), Kúrunmí was appalled at the decision of the king, Aláàfin Àtìbà, to have his son Adélu succeed him, because the latter unjustly abandoned tradition, which required the King's eldest son to die with the king! Kúrunmí was ready to go to war to defend tradition and fight the injustice. The resident Baptist missionary, Revd. Mann, tried to mediate. Referring to the Christian philosophy of turning the other cheek, he suggested that he did not mind if his entire body was cut "if the purpose is in the interest of lasting peace" (Rotimi 1971, 55). Kúrunmí then espoused what he understood as the Yorùbá philosophy of justice and peace. In a moment of comic relief in an otherwise tragic drama, Ola Rotimi had Kúrunmí lecture the British resident about what justice was. Kúrunmí used the analogy of the frog. According to him, when two frogs face each other by the side of a stream, the greetings they exchange teach humans about justice: "you give me, I give you; I give you, you give me" (Bùn mi; Bùn ọ; Bùn ọ, Bùn mi etc.). Kúrunmí concluded thus: "Give and take.' That, my friend, is the best philosophy of life" (ibid.).

Prior to the British incursion into Africa, numerous civil wars were fought between the various tribes of the Yorùbá nation because of perceptions of injustice. Fear of domination by others set some on the path of coalition against the perceived empire builders. After the final collapse of the Oyo empire, the struggle for independence by former satellites of Oyo intensified. Perception of unfairness was at the base of such struggles. If one believes that human beings are children of God, one could criticize a social arrangement because it treats a child of God unfairly or unjustly. 
Ògún is the Yorùbá god of justice and is revered for his uncompromising approach to his responsibility. A common belief is that Ògún will punish anyone that breaks a vow or promise. This was the logic of Kúrunmís intransigence against Aláàfin's insistence that his son succeed him in violation of tradition. In other words, Kúrunmí believed that it was a break of Àtibà's vow and Ògún would support his (Kúrunmí) revolt for the sake of justice. This belief in Ògún's sense of justice is also behind the recent calls for political office holders in Yorùbáland to be made to take their oath of office using Ògún's paraphernalia. The idea is that anyone who embezzles will not get away with it.

\section{Criminal Justice}

Besides conflict situations, the Yorùbá appeal to justice in the evaluation of specific states of affairs. In this regard, it is the fairness or unfairness of such states, whether traditional or modern, that is the target. It is invoked in a popular folk song of the Oyo Yorùbá:

Ó dá mi lẹjọ,,

Ó dá 'mo e láre.

Óf'ọmọ tiẹ lápá relé.

Kò dùn mío.

Ejọ tẹe dá kò dùn mí,

b’ọlọun ò bá pa wá.

He gave me a verdict of guilt.

But he declared his son innocent.

I am not hurt.

Your judgement does not hurt me

provided God spares our lives.

Here the recourse for just judgment is placed in the hands of God. This appeal to the divine power was probably behind Kọrú Ojà's daring accusation against the court of the Aláàfin of Oyo in the heydays of the Oyo empire, Opálábà's defense of the system, and Aróhánrán’s vindication of Kọrú Ojà̀s cynicism. Here, the traditional approach to punitive justice was the focus.

Opálábà, Aróhánrán, and their old friend, Kọrú Ojà were walking down the streets of Oyo Ile town on a sunny day when they noticed the execution arena of the Imperial Majesty, the Aláàfin of Oyo. ${ }^{2}$ Kọrú Ọjà made a

2 I first heard a version of this story from Professor Wande Abimbola, Awise of Yorubaland. 
remark to the effect that most of the so-called culprits executed at the public gallows were innocent: Orí yéye ni Mògún, aláișẹ ló pọ ninu wọn (many of the victims of capital punishment carried out at Mogún are innocent of the crimes of which they were found guilty). Defending the system as incorruptible, Opálábà annoyingly objected to Kọrú Ojà's observation. He basically called Kọú Ojà a liar. Kọú Ojà was offended but did not show it. Aróhánrán nodded in disgust with a mind to teach his friend a lesson. Upon reaching his house, Aróhánrán, under the cover of the night, proceeded straight to the palace backyard where the king's horses were kept. He took the king's favorite horse, beheaded it, and carried the head towards Opálábà's house, making sure that a trail of blood was visible along the way. In the morning, there was pandemonium. The king's horseman was enraged and was fearful for his life. But it soon became clear that the criminal had left a trail, which when followed, led to Opálábà's house.

Opálábà was still fast asleep when the king's security agents knocked on his door. He knew nothing about it and he protested. But he could not explain how the horse's blood traveled from the King's palace to his doorstep. He was promptly arrested and taken to the king's court. Judgement was immediate; it was found he was guilty and must be hanged for the crime. As he was about to be executed, Aróhánrán, his friend, found his way to the front. He asked and was given permission to speak on behalf of his friend. He narrated what had transpired between them, how his friend had defended the system even when their old friend, Kọú Ojà, observed that most alleged culprits killed were innocent. Aróhánrán wanted to teach his friend a lesson and he was pleased that Kọú Ojà was right after all. Opálábà knew nothing about the killing of the king's horse. He, Aróhánrán, was the culprit. But if he had not confessed, Opálábà would have been hanged. In short, Aróhánrán submitted, the system of justice was unjust and corruptible.

Aróhánrán was about to be arrested and hanged in the place of his friend when the king stopped the proceeding. They must not kill Aróhánrán, the king ruled. Rather, they must attend to the observation of Kọrú Ojà and change the system of justice to avoid the killing of innocent people. Indeed, the king sent them to bring Kơrú Ojà to the palace to help him with the system. However, by the time they got to his house, Kọú Ojà was gone, having died suddenly. They were devastated, as they had lost him and his wisdom, and the king had lost a prospective adviser. Now the city lost a prospective benefactor in the court of justice. In a sense, the Nigerian experience has been typical. Honest critics of an unjust system get ridiculed or worse until they die with their wisdom. 


\section{Conceptions of Justice}

One may approach the issue by focusing on Western conceptions of justice. One may then ask "which, if any, of those conceptions is applicable to non-Western (Yorùbá) culture?" A defense of that approach might be that questions about the justice or injustice of some arrangements, e.g. allocation of goods and services or official corruption, etc. cannot be adequately resolved without isolating the conception of justice in use. But this approach assumes that a non-Western, Yorùbá approach to justice must endorse one or the other of those Western conceptions. The assumption is without a solid foundation. Even if it turns out that the non-Western approach appears to share similar foundational assumptions with the Western one, there is no reason why it could not have evolved independently of its Western counterpart in the same way that assumptions about the nature of persons seem to have emerged. While, therefore, there is warrant for the view that non-Western, Yorùbá cultures employ the concept of justice to evaluate social arrangements, an analysis of their conception may reveal an independent foundation. In the same play referred to above, Kúrunmí's subordinates rebelled openly against his leadership because he had not consulted with them before declaring war against $\mathrm{Oyo}$ and Ibadan. They insisted on their right to voluntarily consent (or refuse to consent) to fight the war that Kúrunmí had declared without consulting with them. It was the same mindset that motivated the Iseyin-Okeho Uprising of 1916, when pure illiterates took their destiny into their own hands to seek freedom from colonial imposition.

Yorùbá traditional moral values presuppose a network of relations between adult persons who are conceived to be metaphysical equals. Despite this metaphysical equality, hierarchical ordering of social life is justified on two grounds. First, in response to the order of nature which makes some parents and others, children, there is ordering according to age. Secondly, in response to the social need for stability and common protection, there is need for ordering according to status. Thus, there are kings, queens, and chiefs, and there are subjects. But the original notion of metaphysical equality (each is a child of God) ensures that even kings are only first among equals and subjects retain the right to remove an errant king. One basis for removal is the betrayal of the trust of subjects.

Justice preserves the good of social life by a system of mutual expectations: from society, there is the expectation that a person would contribute her efforts to stability and progress. From the individual, there is the expectation that her needs will be taken care of. At a micro level, it is unfair to me if I help you on your farm and when the time comes you refuse to help me on mine. At the familial level, as able-bodied adults, my wife and I assume the obligation 
to provide for our children's future by giving them good education. At our old age, they have the responsibility to take care of us. After all, this is why the proverbial old Òkété feeds on the milk provided by her daughter. These considerations suggest, I believe, that the idea of justice is central to Yorùbá interpersonal relations. Indeed, one can justifiably posit that one of the essential attributes of Ọmọlúàbí, the quintessential epitome of Yorùbá moral character, is an embrace of and respect for justice.

In the modern political contexts of inter-ethnic relations and the struggles for power that they imply, the Yorùbá have apparently been wedded to and guided by their traditional appeals to justice in the context of social relations, whether family or political.

\section{Justice and the Nationalist Struggle against Foreign Domination}

Foreign rule sneaked into Yorùbáland in 1861 with the annexation of Lagos, which, a year later, became a formal colony of Britain. While missionaries had spread into the Yorùbá hinterland from Abeokuta to Oyo, and from Ogbomosho to Ondo, foreign rulers had remained on the coast. That was to change with time. First, British missionaries and traders needed the protection of the colonial government in their operations. Secondly, the common interest of kings and communities in peace after a long period of civil war intersected with the interest of the British colonial power. Offers of intervention for the sake of peace were made and accepted. Treaties were signed or forced to be signed, followed by the establishment of British rule across Yorùbáland.

As seen above, Yorùbá commoners in Iseyin and Okeho, who were not exposed to Western ideas of freedom and justice, resisted, by appeal to their native intelligence, imposition of foreign notions of governance. It is not a surprise that Yorùbá elite, soundly educated in Western notions of freedom and justice, found strength in the faith of their forebears in the god of justice to demand an end to foreign rule. From Herbert Macaulay's Nigerian National Democratic Party (NNDP), founded in 1923, to Ladipo Solanke's West African Student Union (WASU), founded in 1925, to the Lagos Youth Movement (later named the Nigerian Youth Movement (NYM)), founded in 1934 by J. C. Vaughan, Ernest Ikoli, and Samuel Akinsanya, Yorùbá indigenes, including Sir Adeyemo Alakija, Sir Kofo Abayomi, Dr. Akinola Maja, Obafemi Awolowo, H. O. Davies, Sapara Williams, S. L. Akintola and others, were among the leading lights of the struggle for independence.

It was in the NYM that the Yorùbá fascination with justice first encountered an open conflict of meaning: which, of two approaches, is just? In 1941, a seat became vacant in the Legislative Council and the movement needed 
to choose one of its members as candidate for the seat. The new president of the movement, Dr. Ernest Ikoli, an Ijaw, had expressed interest in the seat. So did Samuel Akinsanya, from Ijebu Remo and Dr. Akinola Maja, a Lagosian Yorùbá. Based on the movement's preexisting policy that gave preference to its president's expressed interest in a vacant position, Chief Awolowo declared support for Ernest Ikoli. Without denying the preexisting policy, Awolowo's position was defeated at the general meeting of the body. Nomination was open to any interested member; a vote was taken and both Ernest Ikoli and Akinola Maja lost to Samuel Akinsanya. But that was not the end of the matter. Based on the precedent in such matters, the result was referred to the executive committee for a final decision. The executive committee reversed the decision of the general meeting by giving the nomination to Ikoli based on existing policy, which Awolowo had espoused. The decision divided the body but Ikoli won the general election and became a member of the Legislative Council.

This story is interesting for two reasons. First, Chief Awolowo, a Remo Yorùbá supported the candidacy of Ernest Ikoli, an Ijaw, against the candidacy of a fellow Remo Yorùbá because he (Awolowo) believed that, in view of the movement's policy of giving preference to its president in case of a vacancy, it was unfair to deprive Ikoli of the nomination. Unfortunately, not everyone saw the matter that way. For those who did not, the existing policy was unfair because it discriminated against members who might have made sacrifices to the movement but did not occupy the office of president. Though Ikoli won, it was a pyrrhic victory. The victory, which hastened the resignation of Azikwe and Akinsanya and their supporters from the movement, effectively ended the dominance of NYM. Secondly, the incident appeared to directly contradict the common perception concerning the ethnic coloration of anti-colonial nationalist struggles. The key actors in this drama debunked that perception with their denial of support for candidates from their ethnic groups. While this may not be obvious in the case of Azikwe's objection to Ikoli's candidacy (Azikwe is Igbo while Ikoli is Ijaw), it is clear in the case of Awolowo's rejection of Akinsanya's candidacy.

\section{Politics of the First Republic and the Price of Justice}

At independence, Nigeria was a federation of three regions-North, West, and East, each with a majority ethnic nationality and a host of minority nationalities whose cultures and languages were under severe threat of extinction. The North had Hausa/Fulani as the majority lording it over the Yorùbá of Kogi and Ilorin, Tivs, the Junkuns, the Idomas, the Kanuris, the Igalas, the Agatus, and many other minority ethnic groups. The West had the Yorùbá as 
majority exerting authority over the Edos, the Izons, the Urhobos, the Ijaws, the Tsekiris, and many other minority groups. The East had the Igbos as majority imposing its will over the Ibibios, the Efiks, the Ijaws, the Ogonis, the Ogojas, and many others. It was clear that, as a matter of fairness and justice, if the country did not replace external colonialism with internal colonialism, the place of ethnic minorities in Nigerian democracy needed attention. Chief Awolowo's Action Group made this issue a major plank of its political manifesto, which called for the creation of states based on linguistic affinity. While his opponents dismissed the effort as a political ploy to win the vote of minorities, Awolowo insisted on the justice of his cause. In the end, the West, which he led, was the only region from which a new region, the Midwest, was carved out by the federal government, ostensibly to satisfy his demand. The Yorùbá, as the nationality identified with the Action Group, paid the price for justice. So did Awolowo, the leader of the party, who personified the Yorùbá obsession with justice in the twentieth-century politics of Nigeria.

The trials and travails of Awolowo at the hands of the ruling coalition of NPC and NNDP, just three years after Nigerian independence, which he and his fellow nationalists fought for, irritated the sense of justice of his Yorùbá compatriots and awakened their sense of resentment and angst. Notwithstanding the social welfare policies of his government, including the introduction of universal free primary education, Awolowo's Action Group struggled for widespread acceptance in Yorùbáland between 1951 and 1960. As the ruling party in the Western Region, the Action Group created the unenviable record of being the first ruling party to lose the general election of 1953 in the Region to the NCNC. However, Awolowo's popularity increased exponentially in 1963 when the federal government arrested him, tried him for treasonable felony, and sent him to ten years in jail. Majority of Yorùbá people at the time believed that the Federal Government's treatment of Awolowo was unfair and that the system was rigged against brave outspoken critics of an unjust system.

Creative artists were moved by the experience of the mid-1960s to remind the Yorùbá of their indigenous fascination with justice and to urge them to think clearly about their place in the scheme of things. Hubert Ogunde's "Yorùbá Ronu" (Yorùbá, Think) was an exemplar.

Mo bojú wayé o, ayé sá mọlámọlá;

Mo mà b'ojú woọrun, òkùnkùn ló șú bo'lẹ;

Mo ni: àréè! Kí ní dé sí Yorùbá ọmo Aládé?

Kí ní șẹlẹ si Yorùbá ọmọ Òduà?

Ye, ye, ye, ye ye, ye! Àwa mà șe hùn! Ợrọ ńlá ń bẹ;

Yorùbá ń șe rawọn nítorí owó,

Yorùbá ń jin r'awon l'ẹsẹ nítorí ipò; 
Wọ́n gbẹbi f'áláre, wọn gbáre f'ẹlẹ́bi;

Wọ́n polè kó wá jà, wọ́n tún poolóko wá mu;

Ogbọn tí wọn gbọn ló gbé wọn délé ọlá, Ogbọn náà ló tún padà wá sì dé wọn mọ́lẹ;

Àwọn tí wọn ti ń șọgá lớjọ tó ti pẹ,

Tún padà wá d'ẹni à ń f'ọwọ tì s'éyin.

Yó, yò, yo, Yorùbá yo yo yo bí iná alé;;

Yorùbá ru ru ru bi omi Òkun;

Yorùbá baba ni baba ń șe...

Yó, yò, yo! Yorùbá ronu o!

I look at the world; it is a cloudy lump

I observe the sky, it is dark and gloomy

I ask in anguish: what has befallen the Yorùbá, the crowned ones?

What has become the lot of Odua descendants?

Alas, we are dumbfounded and worried;

It is a great mystery

The Yorùbá betray themselves for money

The Yorùbá commit fratricide for position

They convict the innocent; they set the guilty free

They invite thieves to rob the farmer and invite the farmer to catch the robbers

They had once assumed leadership position but are now forced to the back The Yorùbá are as bright as the night light

They are as wavy as the ocean current

The Yorùbá must know that elders will always be elders.

Yorùbá, Think!

In addition to the reality of their political experience at the time, the play and the song reawakened the consciousness of the Yorùbá in the matter of social justice and changed the course of events in the second part of the 1960s, not just for the appeal of Awolowo's cause, but also for the way in which the people looked at the politics of the First Republic. Thus, Yorùbá political leaders who aligned with the Northern People's Congress (NPC), with its politics of One North, were perceived as sell-outs concerned only with their own interests, with no sense of social justice. Awolowo's release from prison, his choice as commissioner for finance and vice chair of the Federal Executive Council were perceived as the reparation of justice. The victory of his political party, Unity Party of Nigeria (UPN), in all the states of the old Western Region in the 1979 elections following the return of civil rule was perceived as a vindication of justice. It was also the fulfillment of the hope that Awolowo 
has expressed in his July 1963 message from jail to the Western Regional Conference of the Action Group. That message was titled "The Just Shall Live by Faith" (Awolowo 1981).

\section{Struggle against Military Dictatorship}

The Second Republic of civilian rule collapsed in 1979 due to a combination of factors. The military had tasted the forbidden fruit, itself a perversion of justice because it represented the unjust use of force to take over government from elected representatives of the people. Since the first shot at power benefitted the wielders of the power at the expense of the masses, who suffered not just the indignities of military rule but also the ruinous civil war into which they plunged the country, successive military leaders were eager to have their own turn. The weakness and incompetence of the civilian leaders in the Second Republic provided an excuse for the return of the military. This time, they came with a vengeance and with a perverse idea of social and punitive justice.

The Shagari administration had not been a competent steward of the economy. Chief Awolowo warned against an impending economic disaster. $\mathrm{He}$ was denounced, and then the disaster took place. The military took over and Awolowo, with no position in any government, was subjected to more invasive search and deprivation of his rights (his passports were seized) than Shagari, who was president of the country. Military rule proved disastrous again and it became a relay race between officers. The country was facing imminent ruin and the common men and women were suffering deprivation on all fronts. Agitations against military rule began in the Southwest with the formation of democracy forums and organizations. The sense of justice of the people had been injured and they sought remedy. Public intellectuals, from Nobel laureate Wole Soyinka to Gani Fawehinmi (Senior Advocate of Nigeria, SAN), from Dr. Beko Ransome-Kuti to Femi Falana (SAN) raised their voice and took to the streets in pursuit of justice. While conscientious citizens from other nationalities were counted among the voices of justice, some unhappy people outside the Southwest chided the zone for its propensity for agitation. They were right about the propensity and to understand it is to know what justice means for the generality of the Yorùbá.

The climax of the struggle for social and political justice as the Yorùbá perceive it was reached during the struggle against the annulment of the presidential election of June 12, 1993. For many Nigerians, the annulment of that election was the height of irresponsibility on the part of the Babangida regime. And they put the blame squarely at the doorstep of Babangida himself, as he was the head of the junta and had not hidden his disdain for civil 
rule. He had changed his mind several times on political transition, leading to his self-description as a wily dribbler in the manner of Maradona. However, while many Nigerians judged the annulment an irresponsible and unjust act, not many were willing to do much about it. It was not even a secret that some felt relieved because they were against the candidacy of M. K. O. Abiola, either for personal or ethnic reasons. Therefore, the most organized action against the annulment came from the Southwest and when the National Democratic Coalition (NADECO) was formed, many non-Yorùbá saw it as a Yorùbá forum to pursue the agitation. Indeed, General Oladipo Diya, the Yorùbá lieutenant to General Sani Abacha, derisively referred to NADECO as ÀGBÁKÒ, a play on Yorùbá word for disaster. Dr. Tai Solarin died in the course of the crisis, having participated intensely in the marches. While the military junta deployed deadly attacks on NADECO members with its killer squad, and many were forced into exile, they were not deterred and it was the junta that finally succumbed.

From an honest observation of the politics of Nigeria from the colonial era to the end of the Babangida regime, it should be clear that the acute sense of justice that spurred the Yorùbá-to struggle against colonial imposition, against a wobbly federal system in the First Republic, for minority rights across the length and breadth of the country, and for a truly democratic system that does not punish innocent political opponents-would not have allowed them to accept without protest the annulment of a free and fair election, no matter who the winner was. Therefore, the struggle for Abiola's mandate would have been fought with the same principled determination no matter the ethnic nationality of the winner and victim of the injustice of annulment. The root of the struggle is deeper than considerations of ethnic bond. Needless to say, history is clear about the intra-ethnic Yorùbá struggle for justice as detailed above.

\section{Struggle for Free and Fair Elections}

In a democracy, elections are the means through which we choose those individuals that we believe can effectively best represent our interests in the corridor of power with responsibility for assigning rights and duties and allocating the benefits and burdens of social life. It is therefore important for individuals to be sure that the right people are in the right places. Surely, reasonable citizens know that there will be winners and losers among the candidates that present themselves for office. What they cannot countenance is that losers can be imposed on them as winners. The injustice of such an outcome is obvious. If so, why is it even contemplated? The simple answer is self-interest and greed. But, if it is understood that the will of the voters is what a 
democracy registers and respects, any effort to thwart that will is anti-democratic. For a long time in the history of elections in Nigeria, thwarting the will of voters has been considered a legitimate exercise of political power. But, as I mentioned earlier, the Action Group was the first political party to lose an election as a ruling party in the old Western Region. That was because it allowed the free will of the voters to prevail. Those voters accepted the opposition's campaign propaganda against poll tax, which the Action Group had devised to help pay for the new policy of Universal Free Primary Education. At the next election, however, the same voters saw the benefits of the policy and voted overwhelmingly for the Action Group.

It is unjust to thwart the will of the people expressed through the ballot because it treats them as nonentities. It then imposes on them those individuals that they have not elected. This is done in various ways, including ballot stuffing or simply substituting false numbers for the true results. This practice is widespread and one cannot deny that Yorùbá politicians in various political parties are guilty of it. Especially since the beginning of the Fourth Republic, we have seen challenges to election results from local government elections to general elections at the gubernatorial, national assembly, and presidential levels. Gubernatorial elections have been overturned in Ekiti and Osun, two major Yorùbá states. But the fact that the strongest opposition to electoral malpractice has come from Yorùbáland, including the sponsorship of organizations for its eradication, means that Yorùbá politicians and political leaders take seriously the gravity of the injustice of the practice. With their effort, the importance of electoral integrity is gaining widespread acceptance and the future will not be kind to election riggers. The result of the recent Senatorial election in Osun state where a candidate of the opposition People's Democratic Party (PDP) defeated the candidate of the ruling All Progressives Congress (APC) is good evidence in support of this submission.

\section{The Struggle for Restructuring and True Federalism}

The critical issue of the structure of the country has been the most pressing question for decades, but especially since the beginning of the Fourth Republic. The issue first came to the fore of national discourse in the mid-1980s with the demand for a Sovereign National Conference which was hoped would determine the conditions of our co-existence as a nation. That was in the wake of the devious manipulations of the military. With the annulment of the presidential election of 1993, the demand only grew in intensity until the return of civil rule in 1999. All this while, the Southwest has been the center of gravity for the agitation for restructuring the country. And, some political leaders, 
especially from the North, have not shied away from reading their own meaning into the matter.

In a recent interview with Vanguard News, Tanko Yakassai berated the struggle as a Yorùbá agenda to grab power (Muhammed 2017). While he is right that the demand for a true federal structure has been spearheaded by the Yorùbá since 1959, Yakassai cannot get himself to understand that that demand reflects the Yorùbá fascination with justice and fairness. He cannot understand that while it is anomalous for one region in a federation to be so large, that it can frustrate the will of all other regions combined. That was the case in 1959 until 1966 when new states were created. Rather than see such a system as incongruous with the principles of federalism, Yakassai only saw envy in the demand for restructuring because the agitators just wanted to "deny the North of the benefits of population and landmass." Reference to the North is, of course, a deception. The North is not a monolith. Reference to the North as a population and geographical landmass fails to do justice to the diversity of language and culture, including religion, among the peoples that populate the North. The Midwest was carved out of the Western Region in 1963 on account of the difference in language and culture. But the Northern Region was left intact with its various linguistic groups until 1966. Perhaps if the First Republic had endured and Gowon did not have to confront the impending civil crisis, the North would have remained one region for a long time.

That the Yorùbá have been the leading voices in the struggle for restructuring is not out of character. It is consistent with their aversion to social injustice and to the furtherance of unity in diversity which can only be realized when all parties of Project Nigeria feel that they are not marginalized culturally and economically. The demand for true federalism is anchored in the belief that overconcentration of power and resources in the center is inimical to the wellbeing of citizens in the states or regions. The states are closer to the people and know best what their needs are. Therefore, it makes sense to give more power and resources to the states. Surely, if this becomes a policy, the states of the North and their citizens will benefit as much as southern states and their citizens.

\section{Conclusion}

In the foregoing, my concern has been to highlight some interesting features of the fascination of the Yorùbá with issues of justice and political justice. I have observed that justice is central to the intra-national and intra-cultural interactions among the Yorùbá. Judgments of justice are inescapable in inter-personal relations at the most basic levels. From here, it is only a 
short step to the socio-political contexts and inter-ethnic and inter-cultural affairs. This explains the prominence of Yorùbá voices and actions in Nigeria-wide discourse on and struggle for justice, from the first encounters with foreign rule to the most recent efforts to restructure the country.

\section{Works Cited}

Atanda, J. A. "The Iseyin-Okeho Rising of 1916: An Example of Socio-political Conflict in Colonial Nigeria," Journal of the Historical Society of Nigeria, Vol. IV, No. 4. June, 1969, 497-514.

Awolowo, Obafemi. "The Just Shall Live by Faith," in Obafemi Awolowo, Voice of Reason: Selected Speeches of Chief Obafemi Awolowo, Volume 1. Akure: Fagbamigbe Publishers, 1981 200-206.

Gbadegesin, Segun. African Philosophy: Traditional Yoruba Philosophy and Contemporary African Realities. New York: Peter Lang, 1991.

Gbadegesin, Segun. Okeho in History Mitchellville: Harvest Day Publications, 2017.

Ladele, T. A. A. and Oyedemi, S. A. Iwe Itan Okeho 1750-1978.

Muhammad, AbdulSalam. Interview with Tanko Yakassai: "Restructuring: The Southwest Has Troubled Nigeria Since 1953," The Vanguard, July 31, 2017.

Rotimi, Ola. Kúrunmí: An Historical Tragedy. Oxford: Oxford University Press, 1971. 